\title{
Avaliação de dois métodos de trituração foliar de Acianthera ciliata (Orchidaceae) para extração de DNA
}

\author{
Eliane Cristina Moreno de PEDRI ${ }^{*}$, Catiane dos Santos BRAGA², Carlos Alberto da Cunha OLIVEIRA³, \\ Auana Vicente TIAGO ${ }^{1}$, Ana Aparecida Bandini ROSSI ${ }^{1}$
}

\begin{abstract}
1Programa de Pós-Graduação em Biodiversidade e Biotecnologia (Rede Bionorte), Faculdade de Ciências Biológicas e Agrárias, Universidade do Estado de Mato Grosso, Alta Floresta, MT, Brasil. (ORCID: *; 0000-0001-9556-9491; 0000-0002-8318-5375)

${ }_{2}^{2}$ Programa de Pós-Graduação em Genética e Melhoramento de Plantas, Faculdade de Ciências Biológicas e Agrárias, Universidade do Estado de Mato Grosso, Alta Floresta, MT, Brasil. (ORCID: 0000-0002-8374-6339)

3Programa de Pós-Graduação em Genética e Melhoramento de Plantas, Universidade do Estado de Mato Grosso, Cáceres, MT, Brasil. (ORCID: 0000-0001-7056-1004)

*E-mail: elicmbio@gmail.com (ORCID: 0000-0002-7044-581X)
\end{abstract}

Recebido em: 18/09/2018; Aceito em: 30/11/2019; Publicado em: 04/02/2020.

\begin{abstract}
RESUMO: O estabelecimento de protocolo de extração de DNA de espécies vegetais é uma técnica empregada para a obtenção de um DNA puro e de qualidade. Diante disso, objetivou-se neste estudo padronizar um protocolo para a extração de DNA da espécie Acianthera ciliata, visando posteriores estudos de diversidade genética. Foram testados dois métodos de trituração do tecido foliar, sendo eles: Tampão STE e nitrogênio líquido. Para cada método de trituração foram testadas duas concentrações de $\beta$-mercaptoetanol $(0 \%$ e $2 \%)$. Os dois métodos utilizados, foram eficientes na extração do DNA genômico de $A$. ciliata. As amostras extraídas com $0 \%$ de $\beta$-mercaptoetanol, para os dois métodos, STE e nitrogênio líquido, apresentaram menor quantidade de DNA quando comparado com as amostras extraídas com $2 \%$ de $\beta$-mercaptoetanol. Os dois primers testados amplificaram regiões do genoma de $A$. ciliata. Para a extração de DNA de $A$. ciliata indicase a utilização de CTAB 5\% no tampão de extração e $\beta$-mercaptoetanol a $2 \%$. Os iniciadores ISSR foram eficientes na amplificação e são recomendados para estudos de diversidade genética de $A$. ciliata.

Palavras-chave: diversidade genética; CTAB; marcadores moleculares; orquídeas.
\end{abstract}

\section{Evaluation of two maceration methods in Acianthera ciliata (Orchidaceae) leaves for DNA extraction}

\begin{abstract}
The establishment of DNA extraction protocol for plant species is a technique employed to obtain pure and good quality DNA. In this study, we standardized a protocol for the extraction of DNA of the species Acianthera ciliata, aiming studies of genetic diversity subsequently. Two maceration methods for foliar tissue were tested, and they were STE buffer and liquid nitrogen. Two concentrations of $\beta$-mercaptoethanol $(0 \%$ and $2 \%)$ were tested for each method. The two methods used were efficient for genomic DNA extraction of $A$. ciliata. In both methods the samples extracted using $0 \%$ of $\beta$-mercaptoethanol, they presented lesser amount of DNA than the samples extracted using $2 \%$ of $\beta$-mercaptoethanol. The two tested primers amplified genomic regions of $A$. ciliata. For the DNA extraction of $A$. ciliata, we indicated the use of CTAB $5 \%$ in the extraction buffer as well as $\beta$-mercaptoethanol to $2 \%$. The ISSR primers were efficient in amplification and thus they are indicated for studies of genetic diversity of $A$. ciliata.
\end{abstract}

Keywords: genetic diversity; CTAB; molecular markers; orchids.

\section{INTRODUÇÃO}

Acianthera ciliata (Knowles \& Westc.) F. Barros \& L. Guimarães pertence à família Orchidaceae, umas das maiores do reino vegetal com cerca de 899 gêneros e aproximadamente 27.801 espécies descritas, com maior diversidade nas regiões tropicais e subtropicais (THE PLANT LIST, 2013; FLORA DO BRASIL, 2018).

As orquídeas, no geral, chamam atenção pela variedade de formas e exuberância de suas flores, e por isso, algumas espécies estão ameaçadas de extinção por práticas extrativistas e coletas predatórias que promovem a devastação do seu ambiente natural (COLOMBO et al., 2004). Devido a essa ameaça, estudos moleculares são uma importante ferramenta para analisar a diversidade genética, visto que, auxiliam no desenvolvimento de estratégias mais efetivas para manutenção dos recursos genéticos e conservação das espécies (SILVA et al., 2014).

A trituração adequada do material vegetal é essencial para obtenção de um DNA genômico puro, de qualidade e em quantidades suficientes para o uso (DEVI et al., 2013). Nesta etapa da extração, o rompimento das paredes celulares ocorre através do congelamento do tecido vegetal em nitrogênio líquido e posterior quebra mecânica, ou com uso de tampão (ROMANO; BRASILEIRO, 1999).

A constituição única de cada material vegetal evidencia a necessidade de conhecer o método de trituração mais 
eficiente, com intuito de otimizar os procedimentos posteriores a extração do DNA, além disso, como destaca Collard; Mackill, (2008) alternativas às formas de trituração pode significar redução de tempo e de custos por amostra.

O método CTAB (Brometo de Cetiltrimetilamônio) é o protocolo de extração de DNA mais utilizado para diferentes espécies (DOYLE; DOYLE, 1987), ou com modificações específicas para cada uma, visto que cada vegetal apresenta peculiaridades quanto ao nível de DNA presente nas amostras ou devido à presença de metabolitos secundários, como fenóis e polissacarídeos, que interferem na integridade do DNA (LI et al., 2017).

A otimização nos protocolos de extração é realizada para que a obtenção do DNA seja um processo rápido, simples e de baixo custo (MELLO et al., 2015), proporcionando uma eficaz amplificação via Reação em Cadeia da Polimerase (PCR) utilizando marcadores moleculares dominantes e/ou codominantes (BORÉM; CAIXETA, 2016). Dentre os marcadores dominantes destaca-se os ISSR (Inter Simple Sequence Repeats) que amplificam uma sequência de DNA delimitada por duas regiões microssatélites e têm-se mostrado eficientes em estudos de diversidade genética de distintas espécies vegetais (SANTANA et al., 2011; SILVA et al., 2016; PONTES et al., 2017). Diante do exposto, objetivou-se neste estudo padronizar um protocolo para a extração de DNA da espécie Acianthera ciliata, visando posteriores estudos de diversidade genética.

\section{MATERIAL E MÉTODOS}

O estudo foi conduzido no Laboratório de Genética Vegetal e Biologia Molecular da UNEMAT, campus de Alta Floresta, MT. Para a realização dos testes de extração de DNA foi coletado material foliar de dois indivíduos de Acianthera ciliata (Figura 1A) no Orquidário Altaflorestense da UNEMAT, campus de Alta Floresta (951'41.31"S; $\left.56^{\circ} 4^{\prime} 2.30^{\prime \prime} \mathrm{O}\right)$. Foram extraídos cerca de $200 \mathrm{mg}$ de tecido foliar seguindo o método CTAB proposto por Doyle; Doyle, (1987) com alterações, conforme descrito na Tabela 1.

Tabela 1. Testes de extração de DNA em Acianthera ciliata. Table 1. DNA extraction tests on Acianthera ciliata.

\begin{tabular}{ccc}
\hline Indivíduo & Método de extração & $\beta$-mercaptoetanol \\
\hline 1 & STE & $0 \%$ \\
2 & STE & $0 \%$ \\
1 & STE & $2 \%$ \\
2 & STE & $2 \%$ \\
1 & Nitrogênio & $0 \%$ \\
2 & Nitrogênio & $0 \%$ \\
1 & Nitrogênio & $2 \%$ \\
2 & Nitrogênio & $2 \%$ \\
\hline
\end{tabular}

No estudo, foram testados dois métodos de trituração do tecido foliar, sendo eles: Tampão STE (Figura 1B) (130 g de sacarose, 4,5 $\mathrm{ml}$ de Tris $\mathrm{HCl} 1 \mathrm{M}, 15 \mathrm{ml}$ de EDTA 0,5M, completando o volume com água destilada para $1500 \mathrm{ml}$ ) e nitrogênio líquido (Figura 1C). No tampão de extração foi testado duas concentrações de $\beta$-mercaptoetanol $(0 \%$ e $2 \%)$.

As folhas foram trituradas em almofariz de porcelana com auxílio do pistilo em seguida, juntamente com o material vegetal, foram acrescentados $800 \mu \mathrm{L}$ de Tampão CTAB (100 mM Tris- $\mathrm{HCl}, \mathrm{pH} 8,0 ; 1,4 \mathrm{M}$ Cloreto de Sódio; $20 \mathrm{mM}$ EDTA; $5 \%$ de CTAB e $2 \%$ de PVP), sendo o $\beta$ - mercaptoetanol adicionado separadamente. Os microtubos foram agitados em vórtex (Figura 1D) e posteriormente incubados a $65^{\circ} \mathrm{C}$ por 30 minutos em banho-maria (Figura 1E,F). A cada 10 minutos as amostras foram vertidas para homogeneização da solução. Em seguida os microtubos foram centrifugados por 10 minutos a $10.000 \mathrm{rpm}$. O sobrenadante foi retirado e transferido para um novo microtubo de $2 \mathrm{~mL}$ ao qual adicionou-se $700 \mu \mathrm{L}$ de clorofórmio: álcool isoamílico (24:1). As amostras foram agitadas em vórtex por 30 segundos e novamente centrifugados por 10 minutos a $12.000 \mathrm{rpm}$. A fase aquosa superior foi transferida para um novo microtubo de $1,5 \mathrm{~mL}$ ao qual se adicionou $500 \mu \mathrm{L}$ de isopropanol gelado (álcool isopropílico). As amostras foram armazenadas a $-20{ }^{\circ} \mathrm{C}$ por três horas.

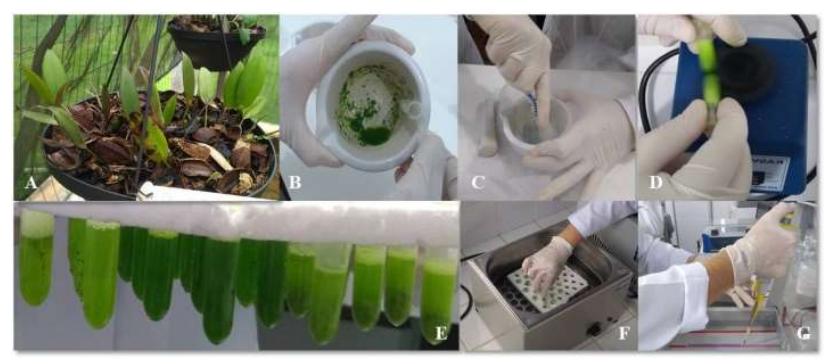

Figura 1. (A) Indivíduo adulto de Acianthera ciliata; (B) Trituração com Tampão STE; (C) Trituração com nitrogênio líquido; (D) Agitação em vórtex; (E, F) Microtubos sendo incubados a $65^{\circ} \mathrm{C} \mathrm{em}$ banho-maria; $(G)$ Quantificação do DNA em gel de agarose 1\%.

Figure 1. (A) Adult individual of Acianthera ciliata; (B) Crushing with STE buffer; (C) Crushing with liquid nitrogen; (D) Vortex agitation; (E, F) Microtubes being incubated at $65^{\circ} \mathrm{C}$ in a water bath; DNA quantification on $1 \%$ agarose gel.

Após este período, as amostras foram centrifugadas a $12.000 \mathrm{rpm}$ por 10 minutos e em seguida descartado o sobrenadante. Realizou-se duas lavagens do precipitado, duas vezes com etanol $70 \%$ e uma vez com etanol $95 \%$, a cada lavagem as amostras foram centrifugadas por 3 minutos a $10.000 \mathrm{rpm}$. Após a secagem do pellet em temperatura ambiente o material foi ressuspendido em $40 \mu \mathrm{L}$ de TE $(10$ $\mathrm{mM}$ Tris-HCl; $1 \mathrm{mM}$ EDTA) contendo RNAse em concentração de $40 \mu \mathrm{g} / \mathrm{mL}$ em cada microtubo. Em seguida, o material foi levado em banho-maria por 30 minutos a 35 ${ }^{\circ} \mathrm{C}$, para dissolver o pellet, e então foram levadas à geladeira a $4{ }^{\circ} \mathrm{C}$ por 24 horas e depois armazenadas a $-20{ }^{\circ} \mathrm{C}$.

Para avaliar a qualidade e a concentração do DNA extraído, as amostras foram submetidas à eletroforese em gel de agarose $1 \%$ e comparadas com o marcador de DNA $\lambda$ de $100 \mathrm{ng} / \mu \mathrm{L}$ (Figura 1G). O gel foi corado com brometo de etídio (EtBr), visualizado em transiluminador com luz UVB (Loccus Biotecnologia ${ }^{\circledR}$ - LTB-STi), fotografado e editado em fotodocumentador L-Pix STi (Loccus Biotecnologia ${ }^{\circledR}$ ) e software L-Pix STi Image, respectivamente. Após a quantificação, o DNA foi diluído à aproximadamente 10 $\mathrm{ng} / \mu \mathrm{L}$ de concentração, utilizando água Milli-Q e posteriormente armazenado a $-20{ }^{\circ} \mathrm{C}$.

Para o teste de amplificação via PCR (Reação em Cadeira da Polimerase) foram utilizados dois primers ISSR (Inter Simple Sequence Repeat) desenvolvidos pela University of British Columbia (UBC), Vancouver, Canadá (Tabela 2). As reações foram realizadas conforme Rossi et al. (2014) com alteração nas concentrações, sendo estas padronizadas em um volume 
final de $20 \mu \mathrm{L}$ contendo: $2 \mu \mathrm{L}$ de Tampão 10X (500 mM de $\mathrm{KCl}, 200 \mathrm{mM}$ de Tris e 0,1\% de tween 20); $2 \mu \mathrm{L}$ de Cloreto de Magnésio $(50 \mathrm{mM}) ; 1 \mu \mathrm{L}$ de DMSO; $4 \mu \mathrm{L}$ de d dNTPs $(1 \mathrm{mM}) ; 0,2 \mu \mathrm{L}$ de Taq polimerase; $3 \mu \mathrm{L}$ de primer, $0,5 \mu \mathrm{L}$ de DNA $(10 \mathrm{ng} / \mu \mathrm{L})$ e água destilada autoclavada para completar o volume.

As amplificações foram conduzidas em termociclador (Aeris), utilizando protocolo proposto por Rodrigues et al. (2015), com modificações, sendo uma desnaturação inicial a $94^{\circ} \mathrm{C}$ por 1,5 minutos, seguida de 35 ciclos de $94{ }^{\circ} \mathrm{C}$ por 40 segundos, $48{ }^{\circ} \mathrm{C}$ por 45 segundos e $72{ }^{\circ} \mathrm{C}$ por 1,5 minutos, concluindo com uma extensão final de $72{ }^{\circ} \mathrm{C}$ por 5 minutos.

Tabela 2. Primers ISSR testados para amplificação do DNA de Acianthera ciliata.

Table 2. ISSR primers tested for DNA amplification of Acianthera ciliata.

\begin{tabular}{ccc}
\hline Primer & Sequência 5' $\rightarrow 3^{\prime}$ & TA $\left({ }^{\circ} \mathrm{C}\right)$ \\
\hline UBC 840 & GAGAGAGAGAGAGAGAYT* & 48 \\
UBC 842 & GAGAGAGAGAGAGAGAYG* & 48 \\
\hline *Y = C ou T. TA = temperatura de anelamento
\end{tabular}

\section{RESULTADOS}

Os dois métodos de trituração do tecido foliar utilizado, Tampão STE e nitrogênio líquido, foram eficientes na extração do DNA genômico de Acianthera ciliata (Figura 2).

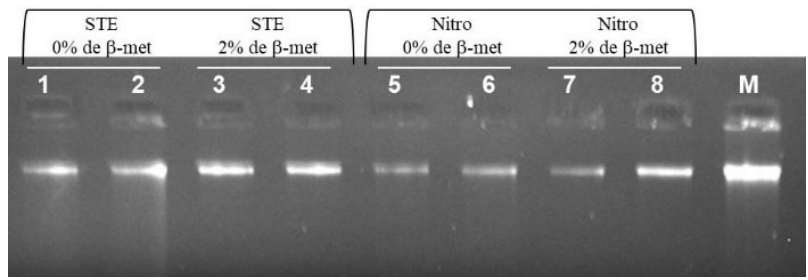

Figura 2. DNA total de Acianthera ciliata. 1 a 4 trituração com Tampão STE (0 e 2\% $\beta$-mercaptoetanol, respectivamente), 5 a 8 com nitrogênio líquido ( 0 e $2 \% \beta$-mercaptoetanol, respectivamente). M: marcador de DNA de $100 \mathrm{ng} / \mu \mathrm{L}$.

Figure 2. Total DNA of Acianthera ciliata. 1 to 4 trituration with STE buffer ( 0 and $2 \% \beta$-mercaptoethanol, respectively), 5 to 8 with liquid nitrogen ( 0 and $2 \% \beta$-mercaptoethanol, respectively). M: DNA marker of $100 \mathrm{ng} / \mu \mathrm{L}$.

Os resultados indicam que o DNA extraído é de boa qualidade por apresentar bandas integras e não haver material retido no poço do gel, indicando que não houve contaminação por polissacarídeos. Contudo, as amostras trituradas com Tampão STE e nitrogênio líquido com $0 \%$ de $\beta$-mercaptoetanol apresentam arraste vertical $(1,2,5,6)$, quando comparado ao uso de ambos os métodos de trituração com $2 \%$ de $\beta$-mercaptoetanol $(3,4,7,8)$.

De maneira geral, as amostras extraídas com $0 \%$ de $\beta$ mercaptoetanol $(1,2,5,6)$, para os dois métodos de extração (STE e nitrogênio líquido), apresentaram menor quantidade de DNA quando comparado com as amostras extraídas com $2 \%$ de $\beta$-mercaptoetanol.

Os primers ISSR utilizados foram eficientes e amplificaram as amostras testadas independentemente do método de trituração e da ausência ou presença de $\beta$-mercaptoetanol (Figura 3). A amplificação via PCR apresentou um padrão de bandas nítidas no gel de agarose, podendo essas condições de extração e amplificação ser utilizadas em posteriores estudos moleculares.

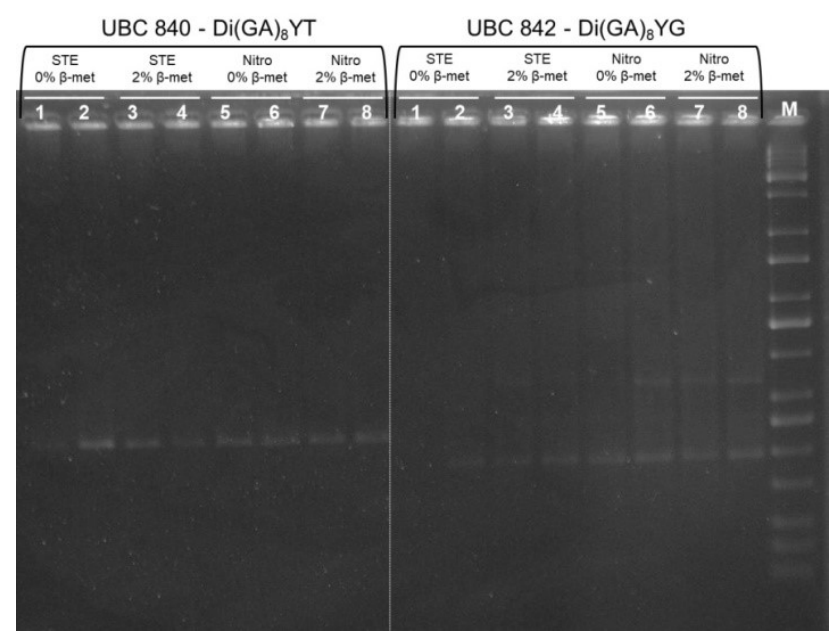

Figura 3. Produtos de amplificação do DNA genômico de Acianthera ciliata com os primers UBC 840 e UBC 842. M: marcador 100 pb DNA Ladder.

Figure 3. Amplification products of Acianthera ciliata genomic DNA with primers UBC 840 and UBC 842. M: 100 bp DNA Ladder marker.

\section{DISCUSSÃO}

Obter um DNA genômico com qualidade ideal para o desenvolvimento de técnicas moleculares é o primeiro passo para a detecção da variabilidade genética em nível molecular (SILVA et al., 2015) e como destaca Nagarajan et al. (2011) o método de trituração do tecido foliar utilizado na extração do DNA genômico influencia diretamente na quantidade e qualidade do material obtido. Contudo, estudos vêm relatando dificuldades em isolar DNA em plantas, pelos distintos contaminantes que podem ser encontrados no tecido vegetal (AGBAGWA al., 2012).

Nas etapas da extração do DNA total são utilizados solventes, detergentes, sais e demais substâncias a fim de minimizar o efeito que a presença de alguns compostos do tecido foliar da planta tem sobre a integridade do DNA e que podem interferir na amplificação (ABDEL-LATIF; OSMAN, 2017). Neste estudo, mesmo com o uso desses compostos, foi observado arraste vertical na amplificação do DNA genômico, e conforme Romano; Brasileiro, (1999) os arrastes surgem, possivelmente, pela contaminação por DNAses ou por quebra mecânica durante a extração por clorofórmio.

O $\beta$-mercaptoetanol é um agente antioxidante que inibe a ação de metabólitos secundários presentes no tecido vegetal, e aumentos na sua concentração até $5 \%$ são fundamentais para impedir o efeito desses componentes (ROMANO; BRASILEIRO, 1999). Neste trabalho observou-se que, em ambos os métodos de trituração, a ausência de $\beta$-mercaptoetanol resultou em menor quantidade de DNA extraído, mostrando que é um componente importante no processo de extração de DNA vegetal (Figura 2).

Silva (2010) ao testar diferentes concentrações de $\beta$ mercaptoetanol $(0,0 \%, 0,2 \%, 1,0 \%, 2,5 \%$ e $5 \%)$ na extração de plantas do cerrado, observou maior quantidade e qualidade do DNA extraído nas concentrações acima de 1\%. Já Silva et al. (2014) e Schmitt et al. (2014) observaram que a concentração de $\beta$-mercaptoetanol não interferiu na quantidade de DNA extraído das espécies Anacardium giganteum e Curcuma longa, respectivamente.

Nativa, Sinop, v. 8, n. 1, p. 97-101, jan./fev. 2020. 
Dalbosco et al. (2015) em seus estudos com a família Orchidaceae, obtiveram resultados satisfatórios com concentrações diferentes, das utilizadas neste estudo, de CTAB (2\%) e $\beta$-mercaptoetanol $(2,5 \%)$, evidenciando, portanto, que cada espécie, muitas vezes dentro da própria família, apresenta compostos químicos distintos que interferem na integridade do DNA e como destaca Ferreira; Grattapaglia (1998) a integridade do DNA genômico é essencial para a uma clara e reprodutível amplificação via PCR. Silva et al. (2015) observaram ainda, em testes com Eucalyptus camaldulensis, que o emprego do $\beta$-mercaptoetanol e do PVP, em conjunto, no tampão de extração, apresentou menor contaminação por proteínas e outras moléculas, ou seja, manteve o DNA integro e preservado.

No processo de extração do DNA, o nitrogênio líquido é o mais utilizado (KOTCHONI; GACHOMO, 2009) pela sua eficiência comprovada em romper a membrana e a parede celular da planta, contudo, o tampão STE também se mostrou eficaz para essa função. Isso mostra que esse tampão pode ser uma alternativa menos onerosa na condução dos experimentos laboratoriais com a espécie, já que, quando são necessárias extrações de várias amostras, a aquisição de nitrogênio líquido implica em custos mais elevados.

O marcador ISSR mostrou-se útil na amplificação via PCR de Acianthera ciliada independentemente do método utilizado, mostrando potencial para avaliação da diversidade genética da espécie. É um marcador amplamente utilizado em estudos genéticos, especialmente porque acelera a análise de variabilidade e seleção (SILVA et al., 2016), possibilitando analisar a diversidade genética e as relações evolutivas de indivíduos, devido a sua abundância e dispersão no genoma (REDDY et al., 2002). Em orquídeas, os marcadores ISSR tem se revelado ser um recurso valioso em distintos estudos de variabilidade genética e filogenia (GEORGE et al., 2009; PINHEIRO et al., 2012; FAJARDO et al., 2014; RODRIGUES et al., 2015).

\section{CONCLUSÕES}

Os dois métodos de trituração (Tampão STE e nitrogênio líquido) foram eficientes na extração do DNA de Acianthera ciliata. A concentração $2 \%$ de $\beta$-mercaptoetanol proporcionou maior quantidade e qualidade de DNA.

Os iniciadores ISSR podem ser utilizados em estudos da diversidade genética de $A$. ciliata.

\section{AGRADECIMENTOS}

O presente trabalho foi realizado com apoio da Coordenação de Aperfeiçoamento de Pessoal de Nível Superior - Brasil (CAPES) - Código de Financiamento 001.

\section{REFERÊNCIAS}

ABDEL-LATIF, A.; OSMAN, G. Comparison of three genomic DNA extraction methods to obtain high DNA quality from maize. Plant methods, Melbourne, v. 13, n. 1, p. 1, 2017. DOI: http://doi.org/10.1186/s13007-0160152-4

AGBAGWA, I. O.; DATTA, S.; PATIL, P. G.; SINGH, P.; NADARAJAN, N. A protocol for high-quality genomic DNA extraction from legumes. Genetics and Molecular Research, Ribeirão Preto, v. 11, n. 4, p. 4632
4639 ,

2012.

DOI:

http:/ /dx.doi.org/10.4238/2012.September.14.1

BORÉM, A.; CAIXETA, E. Marcadores moleculares. Viçosa: Editora UFV, 2016. 385 p.

COLLARD, B. C. Y.; MACKILL, D. J. Marker-assisted selection: an approach for precision plant breeding in the twenty-first century. Philosophical Transactions of The Royal Society, London, v. 363, n. 1491, p. 557-572, 2008. DOI: http://dx.doi.org/10.1098/rstb.2007.2170

COLOMBO, L. A.; FARIA, R. T.; CARVALHO, J. F. R. P.; ASSIS, A. M.; BATISTA FONSECA, I. C. Influência do fungicida clorotalonil no desenvolvimento vegetativo e no enraizamento in vitro de duas espécies de orquídeas brasileiras. Acta Scientiarum. Agronomy, Maringá, v. 26, n. 2, p. 253-258, 2004. DOI: http://dx.doi.org/10.4025/actasciagron.v26i2.1893

DALBOSCO, E. Z.; SILVA, C. G.; MELHORANÇA, E. A. L; MIRANDA, A. F.; SILVA, C. A. Otimização do protocolo para extração de DNA genômico de Epidendrum viviparum Lindl. (Orchidaceae). Enciclopédia Biosfera, Goiânia, v. 11, n. 21, p. 3236-3243, 2015.

DEVI, K. D.; PUNYARANI, K.; SINGH, N. S.; DEVI, H. S. An efficient protocol for total DNA extraction from the members of order Zingiberales-suitable for diverse PCR based downstream applications. SpringerPlus, Londres, v. 2, n. 1, p. 669, 2013. DOI: https://dx.doi.org/10.1186/2193-1801-2-669

DOYLE, J. J.; DOYLE, J. L. A Rapid DNA isolation procedure for small quantities of fresh leaf tissue. Phytochemical Bulletin, v. 19, n. 1, p. 11-15, 1987.

FAJARDO, C. G.; VIEIRA, F. A.; MOLINA, W. F. Interspecific genetic analysis of orchids in Brazil using molecular markers. Plant Systematics Evolution, Heidelberg, v. 300, n. 8, p. 1825-1832, 2014. DOI: http://dx.doi.org/10.1007/s00606-014-1009-9

FERREIRA, M. E.; GRATTAPAGLIA, D. Introdução ao uso de marcadores moleculares em análise genética. 3. ed. Brasília, DF: Embrapa Recursos Genéticos e Biotecnologia, 1998. 220 p. (Documentos, 20).

FLORA DO BRASIL. Orchidaceae. Jardim Botânico do Rio de Janeiro. Disponível em: <http://reflora.jbrj.gov.br/reflora/floradobrasil/FB241 16>. Acesso em: 05 Jul 2018.

GEORGE, S.; SHARMA, J.; YADON, V. L. Genetic diversity of the endangered and narrow endemic Piperia yadonii (Orchidaceae) assessed with ISSR polymorphisms. American Journal of Botany, Farmington, v. 96, n. 11, p. 2022-2030, 2009. DOI: https://dx.doi.org/10.3732/ajb.0800368

KOTCHONI, S. O.; GACHOMO, E. W. A rapid and hazardous reagent free protocol for genomic DNA extraction suitable for genetic studies in plants. Molecular Biology Reports, Dordrecht, v. 36, p. 16331636, 2009. DOI: https:dx.doi.org/10.1007/s11033-0089362-9

LI, Y.; ZHAO, H.; YAN, X.; LI, M.; CHEN, P.; ZHANG, S. A universal method for direct PCR amplification of plant tissues. Analytical Methods, Tokyo, v. 9, n. 11, p. 1800-1805, 2017.

DOI: https://dx.doi.org/10.1039/C6AY03156K

MELLO, L. M.; REINIGER, L. S.; MENEGHELLO, G. E.; VILLELA, F. A.; MOTA, M. S. Isolamento de DNA genômico a partir de folhas secas de Erythrina crista-galli 
L., FABACEAE (Corticeira-do-banhado). Revista Thema, Pelotas, v. 12, n. 1, p. 15-32, 2015. DOI: https://dx.doi.org/10.15536/thema.12.2015.15-32.282

NAGARAJAN, S.; STEEPHEN, K. M.; NAIR, R. R.; SETHURAMAN, T.; ALAGAR, P.; GANESH, D. Improved protocol for isolation of genomic DNA from leaf tissues os Phyllanthus emblica Gaertn. Iranian Journal of Biotechnology, Tehran, v. 9, n. 4, p. 307-313, 2011.

PINHEIRO, L. R.; RABBANI, A. R. C.; SILVA, A. V. C.; LEDO, A. S., PEREIRA, K. L. G.; DINIZ, L. E. C. Genetic diversity and population structure in the Brazilian Cattleya labiata (Orchidaceae) using RAPD and ISSR markers. Plant Systematics and Evolution, Heidelberg, v. 298, n. 10, p. 1815-1825, 2012. DOI: https://dx.doi.org/10.1007/s00606-012-0682-9

PONTES, L. C. G.; MOURA, E. F.; MOURA, M. F.; RODRIGUES, S. M.; OLIVEIRA, M. S. P.; CARVALHO, J. E. U.; THERRIER, J. Caracterização molecular de progênies de bacurizeiro (Platonia insignis) da Ilha de Marajó, nordeste da Amazônia. Acta Amazônica, Manaus, v. 47, n. 4, p. 293-300, 2017. DOI: http://dx.doi.org/10.1590/1809-4392201701302

REDDY, M. P.; SARLA, N.; SIDDIQ, E. A. Inter simple sequence repeat (ISSR) polymorphism and its application in plant breeding. Euphytica, Amsterdam, v. 128, p. 917 , 2002.

DOI: http://dx.doi.org/10.1023/A:1020691618797

RODRIGUES, J. F.; VAN DEN BERG, C.; ABREU, A. G.; NOVELLO, M.; VEASEY, E. A.; OLIVEIRA, G. C.; KOEHLER, S. Species delimitation of Cattleya coccinea and C. mantiqueirae (Orchidaceae): insights from phylogenetic and population genetics analyses. Plant systematics and evolution, Heidelberg, v. 301, n. 5, p. 1345-1359, 2015.2 DOI: https://dx.doi.org/10.1007/s00606-014-1156-z

ROMANO, E.; BRASILEIRO, A. C. M. Extração de DNA de plantas. Biotecnologia, Ciência \& Desenvolvimento, Brasília, v. 2, n. 9, p. 40-43, 1999.

ROSSI, A. A. B.; SILVA, I. V.; LAVEZO, A.; DARDENGO, J. F. E.; EBÚRNEO, L.; BONFANTE, L. V. Extração e amplificação de DNA de seis espécies de Catasetum nativas da Amazônia Meridional. Revista de Ciências Agroambientais, Alta Floresta, v. 12, n. 2, p. 133-137, 2014.

SANTANA, I. B. B.; OLIVEIRA, E. J.; SOARES FILHO, W. S.; RITZINGER, R.; AMORIM, E. P.; COSTA, M. A. P. C.; MOREIRA, R. F. C. Variabilidade genética entre acessos de Umbu-Cajazeira mediante análise de marcadores ISSR. Revista Brasileira de Fruticultura, Jaboticabal, v. 33, n. 3, p. 868-876, 2011. DOI: http:/ /dx.doi.org/10.1590/S0100-29452011005000090

SCHMITT, K. F. M.; SILVA, B. M.; ROSSI, A. A. B.; SANDER, N.; SILVA, C. J. Estabelecimento e otimização de protocolo para extração e amplificação de DNA em tecido foliar de Curcuma longa (L). Enciclopédia Biosfera, Goiânia, v. 10, n. 19, p. 15601568, 2014

SILVA, A. Z. C.; COSTA, R. B.; CAMPOS, D. T. S. Comparação de três tampões para extração de DNA genômico de tecidos foliares de Eucalyptus camaldulensis Dehnh. Multitemas, Campo Grande, n. 48, p. 179-193, 2015.

SILVA, B. M.; DALBOSCO, E. Z.; BOTINI, N.; FARIA, R. B.; ROSSI, A. A. B. Protocolo para extração de DNA genômico de Anacardium giganteum W. Hancock Ex Engl. (ANACARDIACEAE). Enciclopédia Biosfera, Goiânia, v. 10, n. 19, p. 2401, 2014.

SILVA, B. M.; ROSSI, A. A. B.; DARDENGO, J. F. E.; ARAUJO, V. A. A. C.; ROSSI, F. S.; OLIVEIRA, L. O.; CLARINDO, W. R. Diversidade genética estimada com marcadores entre sequências simples repetidas em cultivos comerciais de Cupuaçuzeiro. Ciência Rural, Santa Maria, v. 46, n. 1, p. 108-113, 2016. DOI: http://dx.doi.org/10.1590/0103-8478cr20141634

SILVA, M. N da. Extração de DNA genômico de tecidos foliares maduros de espécies nativas do cerrado. Revista Árvore, Viçosa, v. 34, n. 6, p. 973-978, 2010. DOI: http://dx.doi.org/10.1590/S0100-67622010000600002

THE PLANT LIST. Euphorbiaceae. Disponível em: <http://www.theplantlist.org/1.1/browse/A/Euphorbi aceae/>. Acesso em: 23 Ago 2018. 